\title{
Hubungan Diare dengan Status Gizi Balita di Kelurahan Lubuk Buaya Kecamatan Koto Tangah Kota Padang
}

Alania Rosari, Eka Agustia Rini, Masrul

\begin{abstract}
Abstrak
Malnutrisi pada anak masih menjadi masalah kesehatan utama di dunia. Data dari WHO pada tahun 2010 menunjukkan sebanyak $18 \%$ anak usia di bawah lima tahun di negara berkembang mengalami underweight. Keadaan kurang gizi dapat meningkatkan risiko terkena penyakit infeksi karena daya tahan tubuh yang menurun. Sebaliknya, penyakit infeksi juga dapat memengaruhi status gizi karena asupan makanan menurun, malabsorpsi, dan katabolisme tubuh meningkat. Penelitian ini bertujuan untuk menentukan apakah terdapat hubungan antara diare dengan status gizi balita. Jenis penelitian ini adalah studi observasional dengan desain cross sectional. Populasi penelitian adalah ibu dan balita usia 12-60 bulan yang bertempat tinggal di Kelurahan Lubuk Buaya. Sampel yang diambil sebanyak 145 orang dengan metode proportionate random sampling. Data dikumpulkan dengan kuesioner untuk mengetahui riwayat diare dalam sebulan terakhir dan penimbangan berat badan. Data diolah dengan uji statistik chi square menggunakan program SPSS 17.0. Hasil analisis univariat menunjukkan terdapat balita berstatus gizi baik $(84,1 \%)$, status gizi kurang $(13,8 \%)$, dan status gizi buruk $(2,1 \%)$. Terdapat $25,5 \%$ balita yang pernah mengalami diare dengan rerata durasi diare 3,0 hari. Hasil analisis bivariat menunjukkan tidak terdapat hubungan bermakna antara diare dengan status gizi (BB/U) balita di Kelurahan Lubuk Buaya $(\mathrm{p}=0,742)$. Penelitian ini memperlihatkan bahwa tidak terdapat hubungan antara diare dengan status gizi balita di Kelurahan Lubuk Buaya Kecamatan Koto Tangah Kota Padang.
\end{abstract}

Kata kunci: status gizi balita, diare

\begin{abstract}
Malnutrition in children is still a major health problem in the world. Data from WHO in 2010 showed $18 \%$ of children under five years old in developing countries are underweight. Malnutrition may increase the risk of infectious disease because the immune system is decreased. Otherwise, infectious disease can also affect the nutritional status because of decreased food intake, malabsorption, and increased body catabolism. This study aimed to determine association between diarrhea and nutritional status of children. The study was an observational study with cross sectional design. The population is mother and children aged 12- 60 months residing in Lubuk Buaya Village. There are 145 samples taken with proportionate random sampling method. Data were collected with questionnaire to determine the history of diarrhea in the last month and weighing. The data were processed with chi square test by using SPSS 17.0 program. Results of univariate analysis showed that there are children with good nutritional status $(84,1 \%)$, underweight (13,8\%), and poor nutritional status (2,1\%). There are 25,5\% children had diarrhea with average duration of illness 3,0 days. Results of bivariate analysis showed no significant association between diarrhea and nutritional status (weight/age) of children in Lubuk Buaya Village ( $p=0,742$ ). This study showed no association between diarrhea and nutritional status of children in Lubuk Buaya Village, Koto Tangah Subdistrict, Padang City.
\end{abstract}

Keywords: nutritional status of children, diarrhea

Affiliasi penulis : Alania Rosari,

Korespondensi : Fakultas Kedokteran Universitas Andalas, email : alania_dcoins@yahoo.com, Telp: 085263764558

\section{PENDAHULUAN}

Gizi merupakan salah satu indikator untuk menilai keberhasilan pembangunan kesehatan sebuah negara dalam membangun sumber daya manusia yang berkualitas. ${ }^{1}$ Permasalahan gizi yang masih menjadi masalah utama di dunia adalah malnutrisi. Malnutrisi dapat meningkatkan kerentanan anak terhadap penyakit dan mempengaruhi tumbuh kembangnya. $^{2}$

Pada tahun 2010, sebanyak 103 juta anak berusia di bawah lima tahun di negara berkembang mengalami underweight atau berat badan terlalu rendah. ${ }^{3}$ Prevalensi balita yang mengalami masalah gizi berdasarkan berat badan per umur (BB/U) di Indonesia pada tahun 2010 meliputi kasus gizi kurang $13,0 \%$ dan gizi buruk 4,9\%. Prevalensi di Sumatera Barat menunjukkan kasus gizi kurang $14,4 \%$ dan gizi buruk 2,8\%. "Data tersebut memperlihatkan bahwa jumlah balita dengan status gizi kurang di Sumatera Barat masih tinggi di atas persentase rata-rata Indonesia. Berdasarkan hasil pemantauan status gizi
Dinas Kesehatan Kota Padang pada tahun 2011, didapatkan prevalensi balita gizi kurang dengan indikator BB/U sebesar $10,6 \%$ dan balita gizi buruk $1,7 \%{ }^{5}$

Status gizi anak dipengaruhi oleh banyak faktor. Tiga faktor utama yang mempengaruhi status gizi anak yaitu aspek konsumsi, kesehatan anak, dan pengasuhan psikososial. ${ }^{6}$

Diare adalah suatu keadaan yang ditandai dengan bertambahnya frekuensi defekasi lebih dari tiga kali sehari yang disertai dengan perubahan konsistensi tinja menjadi lebih cair, dengan/tanpa darah dan dengan/tanpa lendir. ${ }^{7}$ Diare menjadi penyebab kematian terbanyak nomor dua pada anak berusia di bawah lima tahun dengan 1,5 juta anak meninggal tiap tahunnya. Diare juga merupakan penyebab utama kejadian malnutrisi pada anak berusia di bawah lima tahun. $^{8}$

Prevalensi diare pada kelompok umur 1 - 4 tahun di Indonesia sebanyak $16,7 \%$ dan merupakan prevalensi terbanyak dibandingkan kelompok umur lainnya. Data yang dilaporkan dalam Riskesdas 2007 menunjukkan diare sudah menjadi penyebab kematian terbanyak pada balita di Indonesia dengan persentase $25,2 \%{ }^{9}$ 
Prevalensi diare di Indonesia sebanyak $9 \%$ dan Sumatera Barat termasuk dalam salah satu provinsi dengan prevalensi diare klinis di atas rata-rata yaitu $9,2 \% .{ }^{9}$ Di Kota Padang, diare masih termasuk ke dalam 10 penyakit terbanyak yang diderita masyarakat. Kelompok umur terbanyak adalah anak berusia di bawah lima tahun (45,8\%). ${ }^{10}$ Berdasarkan data diare Kota Padang Tahun 2011, terdapat 11.653 kasus diare dengan jumlah kasus pada balita sebanyak 4755 kasus $(40,8 \%)^{1}$

Penelitian yang dilakukan oleh Scrimshaw, Taylor, dan Gordon (1968) memperlihatkan bahwa terdapat hubungan timbal balik antara diare dan malnutrisi. Diare dapat menimbulkan terjadinya malnutrisi dan sebaliknya, malnutrisi juga bisa menjadi penyebab timbulnya diare. Infeksi mempengaruhi status gizi melalui penurunan asupan makanan, penurunan absorpsi makanan di usus, meningkatkan katabolisme, dan mengambil nutrisi yang diperlukan tubuh untuk sintesis jaringan dan pertumbuhan. Di samping itu, malnutrisi bisa menjadi faktor predisposisi terjadinya infeksi karena menurunkan pertahanan tubuh dan mengganggu fungsi kekebalan tubuh manusia. $^{12}$

Data dari Dinas Kesehatan Kota Padang Tahun 2011 menunjukkan bahwa kasus diare tertinggi di Kota Padang terdapat di Puskesmas Lubuk Buaya $(12,3 \%)$. Jumlah kasus diare pada balita di Puskesmas Lubuk Buaya sebanyak 493 kasus $(34,3 \%)$. Berdasarkan data kasus diare perkelurahan tahun 2011 di wilayah kerja Puskesmas Lubuk Buaya, kasus diare terbanyak ditemukan di Kelurahan Lubuk Buaya dengan 470 kasus (31,5\%). Data dari hasil pemantauan status gizi Dinas Kesehatan Kota Padang Tahun 2011 di Puskesmas Lubuk Buaya memperlihatkan persentase balita dengan status gizi kurang sebanyak $10,02 \%$. Tujuan penelitian ini adalah untuk melihat hubungan antara diare dengan status gizi balita di Kelurahan Lubuk Buaya Kecamatan Koto Tangah Kota Padang.

\section{METODE}

Jenis penelitian adalah studi observasional dengan desain cross sectional. Populasi penelitian adalah balita usia 12-60 bulan di Kelurahan Lubuk Buaya, Kecamatan Koto Tangah, Kota Padang. Sampel berjumlah 145 orang yang diambil berdasarkan metode proportionate random sampling pada $21 \mathrm{RW}$. Kriteria inklusi sampel adalah ibu dan balita berusia 12-60 bulan, bertempat tinggal di Kelurahan Lubuk Buaya, bersedia ikut dalam penelitian dengan menandatangani informed consent, dan ibu yang mampu berkomunikasi dengan baik. Kriteria eksklusi antara lain anak dengan cacat fisik (hidrosefalus, cerebral palsy, dan amputasi anggota gerak) dan anak yang mengalami sakit berat dalam sebulan terakhir, kecuali diare berat. Penelitian dilaksanakan dari bulan Maret 2012 sampai Maret 2013.

Variabel dependen penelitian adalah status gizi yang dinyatakan dengan variabel $\mathrm{BB} / \mathrm{U}$. Alat yang digunakan untuk menimbang berat badan anak yaitu timbangan injak merk Smic dengan kapasitas $150 \mathrm{~kg}$ dan ketelitian $0,1 \mathrm{~kg}$ dan hasilnya dikonversikan ke dalam bentuk nilai terstandar (Z-score) dengan menggunakan baku antropometri balita WHO 2005. Hasil ukurnya yaitu (1) Gizi baik (gizi baik: Z-score $\geq-2,0 \mathrm{~s} / \mathrm{d}$ Z-score $\leq 2,0$; gizi lebih: Z-score $>2,0$ ) dan (2) Gizi kurang (gizi kurang: Z-score $\geq-3,0$ s/d Z-score
$<-2,0$; gizi buruk: Z-score <-3,0). Variabel independen adalah riwayat diare, yaitu bertambahnya frekuensi defekasi lebih dari tiga kali sehari yang disertai dengan perubahan konsistensi tinja menjadi lebih cair, dengan/tanpa darah dan lendir dalam sebulan terakhir. Data didapatkan melalui wawancara langsung dengan hasil ukur pernah menderita diare atau tidak pernah menderita diare dalam sebulan terakhir.

Langkah-langkah pengolahan data yang dilakukan yaitu memeriksa kelengkapan data dari kuesioner, memberikan kode pada setiap data variabel yang telah terkumpul, memasukkan data ke dalam komputer dengan program Microsoft Excell dan Statistical Program for Social Science (SPSS) 17.0, dan memeriksa kembali data yang telah dimasukkan untuk memastikan bahwa data tersebut telah bersih dari kesalahan. Analisis data terdiri dari analisis univariat dan bivariat. Analisis bivariat digunakan untuk mengetahui hubungan antara dua variabel yaitu diare dengan status gizi menggunakan uji chi square dengan derajat kemaknaan $p<0,05$.

\section{HASIL}

\section{Karakteristik Responden Ibu}

Lebih dari setengah responden ibu berada dalam kelompok umur $30-39$ tahun $(51,7 \%)$ dengan rerata umur 33,1 tahun $(S D \pm 5,9)$. Sebagian besar ibu memiliki tingkat pendidikan baik dengan menyelesaikan pendidikan SLTA/sederajat $(53,1 \%)$ dan tamat akademi/perguruan tinggi $(24,1 \%)$. Sebanyak $83,4 \%$ ibu adalah ibu rumah tangga. Persentase jumlah anak dalam keluarga yang paling banyak adalah 2 orang $(32,4 \%)$.

\section{Karakteristik Responden Balita}

Jenis kelamin perempuan ditemukan sebanyak $54,5 \%$ dan laki-laki $45,5 \%$. Sebagian besar balita lahir dengan berat badan normal $(97,9 \%)$ dan ditemukan kasus BBLR sebanyak 2,1\%. Sebanyak 62,8\% balita diberikan ASI eksklusif selama 6 bulan oleh ibunya. Ketersediaan jamban sudah baik karena hampir seluruh responden memiliki jamban keluarga di rumahnya (99,3\%).

\section{Status Gizi Balita}

Tabel 1. Distribusi Balita Berdasarkan Status Gizi BB/U di Kelurahan Lubuk Buaya

\begin{tabular}{ccc}
\hline Status Gizi & Frekuensi & Persentase (\%) \\
\hline Gizi Baik & 122 & 84,1 \\
Gizi Kurang & 20 & 13,8 \\
Gizi Buruk & 3 & 2,1 \\
\hline Jumlah & 145 & 100 \\
\hline
\end{tabular}

X Z-Score $=-1,1(S D \pm 0,9)$ 


\section{Riwayat Diare}

Tabel 2. Distribusi Riwayat Diare Balita dalam Sebulan Terakhir di Kelurahan Lubuk Buaya

\begin{tabular}{|c|c|c|c|c|}
\hline Diare & Frekuensi & \multicolumn{3}{|c|}{ Persentase (\%) } \\
\hline $\mathrm{Ya}$ & 37 & \multicolumn{3}{|c|}{25,5} \\
\hline Tidak & 108 & \multicolumn{3}{|c|}{74,5} \\
\hline Jumlah & 145 & \multicolumn{3}{|c|}{100} \\
\hline \multicolumn{5}{|c|}{$\begin{array}{l}X \text { frekuensi }=1,0 \text { kali }(S D \pm 0,0) \\
X \text { durasi }=3,0 \text { hari }(S D \pm 2,0)\end{array}$} \\
\hline \multicolumn{2}{|c|}{$\begin{array}{l}\text { Tabel 3. Distribusi } \\
\text { Terjadinya Demam }\end{array}$} & Balita & Diare & Berdas \\
\hline Demam & Frekuensi & \multicolumn{3}{|c|}{ Persentase (\%) } \\
\hline Ya & 26 & \multicolumn{3}{|c|}{70,3} \\
\hline Tidak & 11 & \multicolumn{3}{|c|}{29,7} \\
\hline Jumlah & 37 & \multicolumn{3}{|c|}{100} \\
\hline
\end{tabular}

Berdasarkan Tabel 3 dapat dilihat bahwa sebagian besar balita mengalami demam saat diare.

Tabel 4. Distribusi Balita Diare Berdasarkan Terjadinya Penurunan Nafsu Makan

\begin{tabular}{ccc}
\hline Nafsu Makan & Frekuensi & Persentase (\%) \\
\hline Turun & 30 & 81,1 \\
Tidak turun & 7 & 18,9 \\
\hline Jumlah & 37 & 100 \\
\hline
\end{tabular}

Berdasarkan Tabel 4 dapat dilihat bahwa sebagian besar balita mengalami penurunan nafsu makan saat diare.

Tabel 5. Distribusi Balita Diare Berdasarkan Tindakan Perawatan yang Diberikan Saat Sakit

\begin{tabular}{ccc}
\hline Tindakan Perawatan & Frekuensi & $\begin{array}{c}\text { Persentase } \\
(\%)\end{array}$ \\
\hline Bidan/Dokter & 28 & 75,7 \\
Oralit & 2 & 5,4 \\
Dibiarkan saja & 3 & 8,1 \\
Obat tradisional & 3 & 8,1 \\
Obat dari apotek & 1 & 2,7 \\
\hline Jumlah & $\mathbf{3 7}$ & $\mathbf{1 0 0}$ \\
\hline
\end{tabular}

Berdasarkan Tabel 5 dapat dilihat bahwa sebagian besar balita dibawa oleh ibunya ke bidan/dokter untuk mendapatkan perawatan ketika menderita diare.

\section{Analisis Bivariat}

Tabel 6. Hubungan Diare dengan Status Gizi Balita di Kelurahan Lubuk Buaya

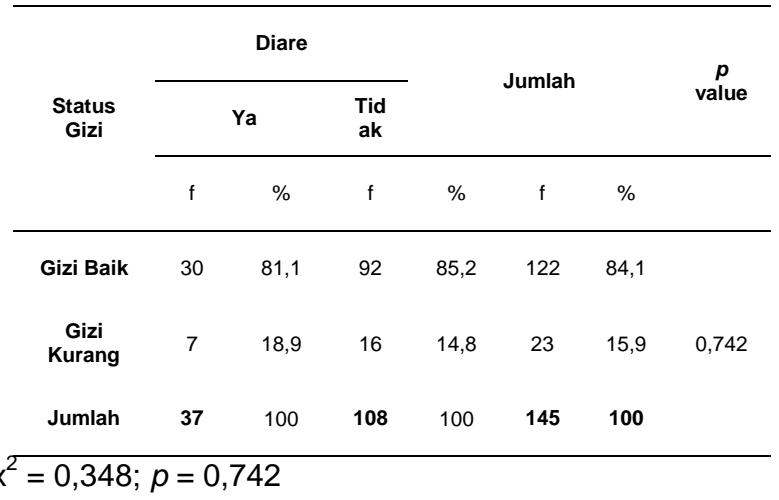

Berdasarkan Tabel 6 dapat dilihat bahwa balita yang mengalami status gizi kurang lebih banyak terjadi pada balita diare dibandingkan dengan balita tidak diare. Namun, perbedaan tersebut secara statistik tidak bermakna $(p>0,05)$.

\section{PEMBAHASAN}

\section{Status Gizi Balita}

Sebagian besar balita memiliki status gizi baik $(84,1 \%)$ dan masih ditemukan balita gizi kurang sebanyak $13,8 \%$ serta gizi buruk $2,1 \%$. Hasil tersebut menunjukkan bahwa persentase balita gizi kurang di Kelurahan Lubuk Buaya masih tinggi bila dibandingkan dengan persentase di Puskesmas Lubuk Buaya $(10,0 \%)$, di Kota Padang (12,4\%), dan di Indonesia (13,0\%). Namun, masih lebih rendah dibandingkan dengan persentase di Sumatera Barat $(14,4 \%)$. Angka kejadian gizi buruk lebih rendah dibandingkan prevalensi di Sumatera Barat $(2,8 \%)$ dan di Indonesia (4,9\%).,5 Keadaan gizi kurang dapat disebabkan kurangnya asupan makanan, terkena infeksi, serta pola pengasuhan yang tidak baik terutama pola asuh makan. ${ }^{13}$

\section{Diare pada Balita}

Kejadian diare pada balita di Kelurahan Lubuk Buaya sebanyak 25,5\%. Angka kejadiannya masih tinggi jika dibandingkan dengan prevalensi diare di Indonesia (16,7\%) dan di negara berkembang lainnya seperti bagian rural Bangladesh (7,6\%).

Menurut Santoso dan Ranti (1995), anak balita lebih rentan menderita penyakit infeksi karena sudah mulai bergerak aktif untuk bermain, sehingga sangat mudah terkontaminasi oleh kotoran. ${ }^{15}$ Pudjiadi (2000) juga menjelaskan bahwa anak usia 2-5 tahun sudah mulai memiliki kebiasaan membeli makanan jajanan yang belum tentu terjaga kebersihannya, baik dalam pengolahan maupun penyajiannya, sehingga sangat mudah terkontaminasi oleh kuman yang bisa menyebabkan diare. ${ }^{16}$

Sebagian besar anak yang menderita diare mengalami demam $(70,3 \%)$ dan penurunan nafsu makan (81,1\%). Demam timbul sebagai respon tubuh saat terjadinya proses inflamasi akibat infeksi dan penurunan nafsu makan atau 
asupan makanan terjadi sejalan dengan tingkat keparahan infeksi. Semakin parah infeksi yang terjadi maka penurunan asupan makanan akan semakin besar. ${ }^{17}$

\section{Hubungan Diare dengan Status Gizi Balita}

Balita yang mengalami status gizi kurang lebih banyak terjadi pada balita diare $(18,9 \%)$ dibandingkan dengan balita tidak diare $(14,8 \%)$. Namun, hasil analisis secara statistik menunjukkan bahwa tidak terdapat hubungan yang bermakna antara kejadian diare dalam sebulan terakhir dengan status gizi balita di Kelurahan Lubuk Buaya $(p>0,05)$.

Penelitian lain yang dilakukan oleh Indriyast di Puskesmas Karawaci Baru Kota Tangerang juga memperlihatkan hasil yang sama dengan peneliti yang menunjukkan bahwa tidak ada hubungan yang signifikan antara kejadian penyakit diare dengan status gizi balita. $^{18}$ Berbeda dengan penelitian yang dilakukan oleh Martianto dkk pada balita di Kabupaten Lembata, Nusa Tenggara Timur yang mendapatkan hubungan signifikan antara keberadaan penyakit infeksi dengan status gizi anak. ${ }^{6}$

Rerata frekuensi diare pada balita adalah 1 kali dalam sebulan terakhir dan rerata durasi diare adalah 3,0 hari $(S D \pm 2,0)$. Penelitian Nurcahyo dkk pada balita usia 12-59 bulan di Kabupaten Bogor menunjukkan bahwa semakin sering frekuensi diare maka status gizi balita menurut BB/U akan semakin buruk. ${ }^{19}$ Demikian pula dengan penelitian yang dilakukan oleh Fatimah yang memperlihatkan bahwa semua anak dengan gizi kurang memiliki riwayat penyakit infeksi seperti diare berulang, ISPA berulang, dan tuberkulosis. ${ }^{20}$

Penelitian yang dilakukan oleh Rusmiati di RSU Dr.Tengku Mansyur Tanjungbalai Medan mendapatkan adanya hubungan antara lamanya kejadian diare dengan status gizi balita menurut $\mathrm{BB} / \mathrm{U}^{21}$ Sebagian besar ibu juga melakukan tindakan yang cepat dalam menanggulangi diare dengan membawa berobat ke tempat pelayanan kesehatan seperti bidan/dokter $(75,7 \%)$ dan memberikan oralit/cairan rumah tangga $(5,4 \%)$. Tindakan tersebut akan memperkecil terjadinya gangguan keseimbangan elektrolit pada anak karena prinsip utama dalam pengobatan diare akut adalah rehidrasi. ${ }^{22}$ Frekuensi diare yang jarang, durasi diare singkat, serta pemberian tindakan penanggulangan yang tepat menyebabkan diare yang terjadi tidak mempengaruhi status gizi balita secara bermakna.

Berdasarkan penelitian ini dapat disimpulkan bahwa kejadian balita gizi kurang di Kelurahan Lubuk Buaya cukup tinggi dan masih ditemukan kejadian balita gizi buruk. Kasus diare pada balita juga masih tinggi dan dari hasil uji statistik tidak terdapat hubungan yang bermakna antara diare dengan status gizi balita usia 12-60 bulan di Kelurahan Lubuk Buaya.

\section{Daftar Pustaka}

1. Departemen Kesehatan RI. Rencana pembangunan jangka panjang bidang kesehatan 2005-2025. Jakarta: 2009.

2. Katz R, Manikam R, Schuberth L. Pediatric and adolescent disorders. Dalam: Shils ME, Shike M, Ross AC, Caballero B, Cousins RJ (editor). Modern nutrition in health and disease. Edisi ke-
10. Philadelphia: Lippincott Williams \& Wilkins; 2006. hlm. 876-80.

3. World Health Organization. Underweight in children. 2010 (diunduh 18 Maret 2012). Tersedia dari:

http://www.who.int/gho/mdg/poverty_hunger/unde rweight text/en/ index.html.

4. Riskesdas. Riset kesehatan dasar 2010. Jakarta: Badan Penelitian dan Pengembangan Kesehatan Kementerian Kesehatan RI; 2010. hlm. 52.

5. Dinas Kesehatan Kota Padang. Pemantauan status gizi dinas kesehatan kota Padang tahun 2011. Padang: 2011.

6. Martianto D, Riyadi H, Hastuti D, Alfiasari, Briawan D. Penilaian situasi pangan dan gizi di kabupaten Lembata, provinsi NTT. Departemen Gizi dan Masyarakat: Institut Pertanian Bogor; 2006.

7. Suraatmaja S. Kapita selekta gastroenterologi anak. Jakarta: Sagung Seto; 2007. hlm. 1-22.

8. World Health Organization. Diarrhoeal disease. 2009 (diunduh 27 Maret 2012). Tersedia dari: http://www.who.intmediacentre/factsheets/fs330/e n/index.html.

9. Riskesdas. Riset kesehatan dasar 2007. Jakarta: Badan Penelitian dan Pengembangan Kesehatan Kementerian Kesehatan Rl; 2007. hlm. 154; 325.

10. Dinas Kesehatan Kota Padang. Laporan tahunan tahun 2010 edisi 2011. Padang: 2011

11. Dinas Kesehatan Kota Padang. Data diare kota Padang tahun 2011. Padang: 2012.

12. Brown KH. Diarrhea and malnutrition. J. Nutr. 2003; 133:328S-32S

13. Supriatin A. Analisis faktor-faktor yang mempengaruhi pola asuh makan dan hubungannya dengan status gizi balita (skripsi). Bogor: Institut Pertanian Bogor; 2004.

14. Nutritional Surveillance Project. Nutrition and health surveillance in barisal division. Bangladesh: Helen Keller Worldwide; 2002.

15. Emiralda. Pengaruh pola asuh anak terhadap terjadinya balita malnutrisi di wilayah kerja puskesmas Montasik kecamatan Montasik kabupaten Aceh Besar tahun 2006 (tesis). Medan: Universitas Sumatera Utara; 2007.

16. Palupi A, Hadi $H$, Soenarto SS. Status gizi dan hubungannya dengan kejadian diare pada anak diare akut di ruang rawat inap RSUP Dr. Sardjito Yogyakarta. Jurnal Gizi Klinik Indonesia. 2009;6(Pt 1): 1-7.

17. Scrimshaw NS. Historical concepts of interactions, synergism and antagonism between nutrition and infection. J. Nutr. 2003;133:316S-21S.

18. Indriyasti, S. Hubungan kejadian penyakit diare terhadap status gizi balita di puskesmas Karawaci Baru kota Tangerang (skripsi). Jakarta: Universitas Indonusa Esa Unggul; 2007.

19. Nurcahyo K, Briawan D. Konsumsi pangan, penyakit infeksi, dan status gizi anak balita pasca perawatan gizi buruk. Jurnal Gizi dan Pangan. 2010;5(Pt 3): 164-70

20. Fatimah S, Nurhidayah I, Rakhmawati W. Faktorfaktor yang berkontribusi terhadap status gizi pada balita di kecamatan Ciawi kabupaten Tasikmalaya (laporan akhir penelitian peneliti muda). Bandung: Universitas Padjadjaran; 2008.

21. Rusmiati. 2008. Gambaran pola konsumsi pangan dan status gizi anak balita penderita diare di ruang anak RSU Dr. Tengku Mansyur 
Tanjungbalai tahun 2008 (skripsi). Medan: Universitas Sumatera Utara; 2008.

22. Petri WA, Miller M, Binder HJ, Levine MM,

Dillingham R, Guerrant LR. Enteric infections, diarrhea, and their impact on function and development. J. Clin. Invest. 2008;118(Pt 4): 1277-90. 